\title{
The Application of Family Latrine Construction Model in the Low Economic Community in the Coastal Area in Indonesia During COVID 19 Pandemic
}

\author{
Bakhrani Abdul Rauf ${ }^{1}$, Muhammad Ardi ${ }^{1}$, Faizal Amir ${ }^{2}$, Rahmansah $^{1}$, Andi Yusdy Dwiasta ${ }^{1}$, \\ Alimuddin Sa'ban Miru ${ }^{3}$, Yasdin ${ }^{2}$, Mithen Lullulangi ${ }^{1, ~ *}$ \\ ${ }^{1}$ Department of Civil Engineering and Planning Education, Faculty of Engineering, Universitas Negeri, Makassar, Indonesia \\ ${ }^{2}$ Department of Automotive Engineering Education, Faculty of Engineering, Universitas Negeri, Makassar, Indonesia \\ ${ }^{3}$ Department of Electrical Engineering Education, Faculty of Engineering, Universitas Negeri, Makassar, Indonesia
}

\section{Email address:}

bakhrani@unm.ac.id (B. A. Rauf), m.ardi@unm.ac.id (M. Ardi), faizalamir64@unm.ac.id (F. Amir), Rahmansahr@unm.ac.id (Rahman), andi.yusdi@unm.ac.id (A. Y. Dwiasta), alimuddin.smiru@unm.ac.id (A. S. Miru),yasdin@unm.ac.id (Yasdi),

mithen@unm.ac.id (M. Lullulangi)

${ }^{*}$ Corresponding author

\section{To cite this article:}

Bakhrani Abdul Rauf, Muhammad Ardi, Faizal Amir, Rahmansah, Andi Yusdy Dwiasta, Alimuddin Sa'ban Miru, Yasdin, Mithen Lullulangi. The Application of Family Latrine Construction Model in the Low Economic Community in the Coastal Area in Indonesia During COVID 19 Pandemic. Journal of Civil, Construction and Environmental Engineering. Vol. 5, No. 6, 2020, pp. 161-166. doi: $10.11648 / \mathrm{j}$.jccee.20200506.13

Received: December 7, 2020; Accepted: December 14, 2020; Published: December 25, 2020

\begin{abstract}
The aims of the research report are (1) low-income communities knowledge, attitudes, motivation, and behavior on the making of safe and environmentally friendly latrines and (2) to find the effect of experiments on increasing knowledge, attitudes, motivation, and behavior of low economic communities in the coastal areas of South Sulawesi during Covid-19 Pandemic. The sample of the experimental group are 30 heads of family area was Kanaungan Village, and the control group is 30 heads of family were selected by purposive sampling method area was Ma'rang Village in Pangkep Regency South Sulawesi, one of the Indonesian provinces. The research variables: (1) knowledge, attitude, motivation, and behavior, and (2) the effect of experiments on increasing knowledge, attitudes, motivation, and behavior. The experimental design used was a pretest-posttest control group design. The analysis used is descriptive statistical analysis and inferential statistical analysis. The inferential model is the independent t-test. The results of the research have shown that (1) knowledge, attitudes, motivation, and behavior to use safe and environmentally friendly latrines has increased after the experiments, and (2) there is a significant impact of the experiment in nurturing knowledge, attitudes, motivation, and behavior of the low economic communities in the coastal areas of South Sulawesi.
\end{abstract}

Keywords: Application, Family Latrine, Construction Model, Kanaungan Village, Ma'rang Village, Pangkep Regency

\section{Introduction}

Human feces is a source of various diseases and viruses, so it needs to be dumped in the latrine for environmental safety. If feces are not managed well, it can reduce the quality of the environment and cause various diseases, including the spreading of Covid-19. The Law of the Republic of Indonesia No. 32 (2009) explains that the environment is a unitary environment with all objects, forces, conditions, and living things, including humans and their behavior that affect the continuity of life and the welfare of humans and other living things [1]. Therefore, the good and bad of the built environment is very much determined by the humans themselves, such as providing a family latrine that is safe for the environment.

Singh (2006) states that the environment is composed of three important components, namely: the abiotic environment, the biotic environment, and the sociocultural environment [2]. 
These three components of the environment are dependent on one another so that they need to be maintained. Rauf (2018) stated that family latrine in coastal, lowland, and highland areas are in poor condition and are not safe for the environment [3]. Such family latrines pollute the environment and have the opportunity for spreading Covid19.

In the sociocultural environment, one important aspect, which is a basic human need, namely housing in which there is a family latrine. Rauf (2017) has found a family latrine model and its constituent materials for low economic communities in the coastal areas of South Sulawesi [4]. This latrine model is very significant to be trained to increase the knowledge, attitudes, motivation, and behavior of the low economic community in overcoming Covid-19 and making latrines that are safe for the environment. The existence of this training makes it possible for the low economic communities in the coastal areas of South Sulawesi Province to have knowledge, attitudes, motivation, and high behavior in overcoming Covid-19 and making family latrine that is safe for the environment.

The supporting theory of this research is described as follows. Human feces that are discarded anywhere are a source of disease. Feces that are not managed well, it can affect human health. Petrus Riski (2015) states that feces and urine released by humans if they are not accommodated in a latrine harm environmental quality and public health [5]. Soemirat (2014) states that the family latrine building must fulfill health requirements: protected from heat and rain, odorless, and enough water to clean it [6].

The data research report aims to describe low-income communities attitudes, motivation, and behavior on the use of safe and environmentally friendly latrines and to determine the effect of experiments on increasing knowledge, attitudes, motivation, and behavior of low economic communities in the coastal areas of South Sulawesi during Covid-19 Pandemic

\section{Materials and Methods}

This research is a quasi-experiment research report. The research place is the coastal area of South Sulawesi Province. The experimental area was Kanaungan Village and the control area was Ma'rang Village, Pangkep Regency. The two areas were selected by purposive sampling method. The research sample, namely the experimental group are 30 head of the family, and the control group are also 30 heads of families with the low economic communities.

The variables of the research are as follows:

1. Knowledge, attitudes, motivation, and behavior of the low economic communities built latrines that are safe for the environment during Covid 19 Pandemic.

2. The effect of experiments on increasing knowledge, attitudes, motivation, and behavior of the low economic communities.

The experimental model used was a pretest-posttest control group design [7]. The analysis used is statistical analysis descriptive and inferential statistics. The analysis model used was the independent $t$ test.

\section{Result}

Knowledge, attitudes, motivation, and behavior.

\subsection{Knowledge Before the Intervention}

The results of descriptive statistical analysis of experimental group knowledge before the experiment showed that the average value of knowledge of low-income communities in making latrines that were safe for the environment is 6.72 . The most value is 8 , and the smallest value is 2 . Based on the frequency distribution, it can be seen that the average value is in a low category. Thus, it can be concluded that the knowledge in making latrines that are safe for the environment, in the experimental group before experimenting is in a low category.

On the other hand, the results of descriptive statistical analysis of the control group's knowledge showed that the average value of the control group's knowledge in making latrines that were safe for the environment is 5.32. The most value is 8 , and the smallest value is 1 . Based on the frequency distribution, it can be seen that the average value is in a low category. Thus, it can be concluded that the knowledge of the control group of low-income communities in making latrines that are safe for the environment before experimenting is in a low category.

\subsection{Knowledge After the Intervention}

The result of descriptive statistical analysis of the experimental group's knowledge showed that the average value of knowledge in creating latrines that are safe for the environment is 14.72 . The most value is 18 , and the least value is 10 . Based on the frequency distribution, it can be seen that the average value is in the high category. Thus, it can be concluded that the knowledge of lowincome communities in making latrines that are safe for the environment, after experimenting is in the high category.

However, the result of descriptive statistical analysis showed that the average value of the control group's knowledge in making latrines that were safe for the environment is 5.01. The most value is 8 , and the smallest value is 1 . Based on the frequency distribution, it can be seen that the average value is in a low category.

Thus, it can be concluded that the knowledge of the control group of low-income communities in making latrines that are safe for the environment after experimenting is in a low category.

\subsection{Attitude Before the Intervention}

The result of descriptive statistical analysis of lowincome communities' attitudes in making latrines showed that the mean value is 28.76 . The most value is 31 , and the smallest value is 17 . Based on the frequency 
distribution, it can be seen that the average value is in the negative or low category. Thus, it can be concluded that the attitude of the experimental group of low-income communities in making latrines that are safe for the environment before experimenting is in the negative or low category.

The results of descriptive statistical analysis showed that the mean value is 29.60 . The most value is 36 , and the smallest value is. Based on the frequency distribution, it can be seen that the average value is in the negative or low category. Thus it can be concluded that the attitude of the control group of low-income communities in making latrines that are safe for the environment before experimenting is in the negative or low category.

\subsection{Attitude After the Intervention}

The results of descriptive statistical analysis of lowincome communities' attitude in making latrines showed that the mean value is 64.87 . The most value is 74 , and the smallest value is 48 . Based on the frequency distribution, it can be seen that the average value is in the very positive category. Thus, it can be concluded that the attitude of the experimental group low-income communities in making latrines that are safe for the environment after experimenting is in a very positive or very high category.

Vice versa, the results of descriptive statistical analysis showed that the mean value is 29.60 . The most value is 36 , and the minimum value is 18 . Based on the frequency distribution, it can be seen that the average value is in the negative or low category. Thus it can be concluded that the attitude of the control group of low-income communities in making latrines that are safe for the environment after experimenting is in the negative or low category.

\subsection{Motivation Before the Intervention}

The results of descriptive statistical analysis of lowincome communities' motivation in making latrines showed that the average value is 26.06 . The most value is 34 , and the smallest value is 19. Based on the frequency distribution, it can be seen that the average value is in a low category. Thus, it can be concluded that the motivation of the experimental group of low-income communities' motivation in making latrines that are safe for the environment before experimenting is in a low category.

The results of descriptive statistical analysis of lowincome communities' motivation in making latrines showed that the average value is 21.20 . The most value is 35 , and the smallest value is 16 . Based on the frequency distribution, it can be seen that the average value is in the very low category. Thus it can be concluded that the motivation of the control group of low-income communities' motivation in making latrines that are safe for the environment before experimenting is in the very low category.

\subsection{Motivation After the Intervention}

The results of descriptive statistical analysis of lowincome communities' motivation in making latrines showed that the average value of motivation is 48.45 . The most value is 73 , and the smallest value is 51 . Based on the frequency distribution, it can be seen that the average value is in the high category. Thus, it can be concluded that the motivation of the experimental group of low-income communities' motivation in making latrines that are safe for the environment after experimenting is in the high category.

The results of descriptive statistical analysis of lowincome communities' motivation in making latrines showed that the average value is 29.20 . The most value is 37 , and the smallest value is 18 . Based on the frequency distribution, it can be seen that the average value is in a low category. Thus, it can be concluded that the motivation of the control group of low-income communities' motivation in making latrines that are safe for the environment after experimenting is in a low category.

\subsection{Behavior Before the Intervention}

The results of the descriptive statistical analysis of lowincome communities' behavior in making latrines showed that the mean value of attitude is 25.43 . The most value is 33 , and the smallest value is 18. Based on the frequency distribution, it can be seen that the average value is in the very low category. Thus, it can be concluded that the attitude of the experimental group of low-income communities' behavior in making latrines that are safe for the environment before experimenting is very low.

The results of descriptive statistical analysis of low-income communities' behavior in making latrines showed that the average value is 25.67 . The most value is 37 , and the smallest value is 17 . Based on the frequency distribution, it can be seen that the average value is in the very low category. Thus it can be concluded that low-income communities' behavior in making latrines that are safe for the environment before experimenting is in the very low category.

\subsection{Behavior After the Intervention}

The results of descriptive statistical analysis of lowincome communities' behavior in making latrines showed that the mean value is 61.24 . The most value is 74 , and the smallest value is 49 . Based on the frequency distribution, it can be seen that the average value is in the high category. Thus, it can be concluded that low-income communities' behavior in making latrines that are safe for the environment after experimenting is in the high category.

The results of descriptive statistical analysis of lowincome communities' behavior in making latrines showed that the mean value is 29.10 . The most value is 36 , and the smallest value is 18 . Based on the frequency distributio, it can be seen that the average value is in the very low category. Thus, it can be concluded that low-income communities' behavior in making latrines that are safe for the environment after experimenting is in the very low category. 


\subsection{The Impact on Increasing Knowledge, Attitudes, Motivation, and Behavior}

The results of the inferential analysis (independent t-test) of knowledge of low-income communities in making latrines that are safe for the environment between the experimental group and the control group after experiments are presented in Table 1.

Table 1. The results of inferential analysis (independent t-test) between the experimental group and the control group, after the experiment.

\begin{tabular}{|c|c|c|c|c|c|c|c|c|}
\hline & \multicolumn{5}{|c|}{ Paired Differences } & \multirow[t]{3}{*}{ t } & \multirow[t]{3}{*}{ df } & \multirow[t]{3}{*}{ Sig. (2-tailed) } \\
\hline & \multirow{2}{*}{ Mean } & \multirow{2}{*}{ Std. Deviation } & \multirow{2}{*}{ Std. Error Mean } & \multicolumn{2}{|c|}{ 95\% Confidence Interval of the Difference } & & & \\
\hline & & & & Lower & Upper & & & \\
\hline Correlation $=.970$ & 9,86 & 1,00 & 0,21 & 14,72 & 5,01 & 59,00 & 29 & .000 \\
\hline Correlation $=.89$ & 47,235 & ,92 & 64,87 & 47,82 & 29,6 & 62,08 & 29 & .000 \\
\hline Correlation $=.92$ & 38,83 & 1,200 & 48,45 & 47,54 & 29,2 & 52,00 & 29 & .000 \\
\hline Correlation $=.94$ & 45,17 & 0,70 & 0,33 & 61,24 & 29,10 & 59,00 & 29 & .000 \\
\hline
\end{tabular}

In Table 1 , it can be seen that significant $\mathrm{t}=0.000<\alpha=0.05$. This means that the knowledge in making latrines that are safe for the environment between the experimental group and the control group after experimenting was very different. The average value of the experimental group's knowledge $=14.72$. The mean value of the control group's knowledge $=5.01$. The experimental group's knowledge was much higher than the control group's knowledge. The correlation coefficient $=0.970$ or the determination factor $=0.94$. This figure shows that the effect of implementing the experiment is $94 \%$ on increasing knowledge of how to overcome Covid-19 and making latrines that are safe for the environment.

The results of the inferential analysis (independent t-test) of attitudes in making latrines that are safe for the environment between the experimental group and the control group after experiments are presented in Table 1. In Table 1, it can be seen that $\mathrm{t}=0.000<\alpha=0.05$. This means that the attitude in overcoming Covid-19 and making latrines that are safe for the environment between the experimental group and the control group after the experiment was very significantly different. The mean value of the attitude of the experimental group $=64.87$. The mean value of the control group's attitude $=29.60$. The attitude of the experimental group was much higher than that of the control group. The correlation coefficient $=0.89$ or the determination coefficient $=0.79$. This figure shows that the effect of implementing the experiment is $79 \%$ on improving attitudes to overcome Covid-19 and to make latrines that are safe for the environment.

The results of the inferential analysis (independent t-test) of motivation in overcoming Covid-19 and making latrines that are safe for the environment between the experimental group and the control group after experiments are presented in Table 1. In Table 1, it can be seen that significant $\mathrm{t}=0.000$ $<\alpha=0.05$. This means that the motivation in making latrines that are safe for the environment between the experimental group and the control group after experimenting was very different. The average value of the experimental group's motivation $=48.45$. The mean value of the control group's motivation is 29.20. The motivation of the experimental group was much higher than that of the control group. The correlation coefficient is 0.92 or the determination coefficient is 0.85 . This figure shows that the effect of conducting experiments is $85 \%$ on increasing motivation in making latrines that are safe for the environment.

The results of the inferential analysis (independent t-test) of the behavior in making latrines that are safe for the environment between the experimental group and the control group after the implementation of the experiment are presented in Table 1. In Table 1 , it can be seen that $\mathrm{t}=0.000$ $<\alpha=0.05$. This means that the behavior in making latrines that are safe for the environment between the experimental group and the control group after experimenting was very different. The average value of the experimental group's behavior $=61.24$. The average value of the control group's knowledge $=29.10$. The behavior of the experimental group was much higher than the behavior of the control group. Correlation coefficient $=0.94$ or determination coefficient $=0.88$. This figure shows that the effect of implementing the experiment is $88 \%$ on increasing behavior in overcoming Covid-19 and making latrines that are safe for the environment.

The increasing of knowledge, attitudes, motivation, and behavior of the community as described earlier is caused by (1) the community was enthusiastic in participating in the training, (2) the experimental material (training) provided includes material needed and preferred by the community, and (3) in the implementation of experiments are carried out controlling the testing effect, maturation effect, and mortality effect. The enthusiasm for taking part in the training got high knowledge. The high knowledge creates high attitudes and motivation. The high knowledge, high attitudes, and motivation towards overcoming Covid-19 and how to make latrines that are safe for the environment creates high behavior.

\section{Discussion}

The findings above say what Fitriani (2011) states that latrines are constructions in which human feces are disposed of in such a way that they do not cause odors and germs, and do not disturb aesthetics [8]. Firmansyah (2009) and Atika (2012) state that latrines in rural Indonesia are classified into two types, namely slotted latrine and septic tank/goose neck latrines [9]. Atika (2012) states that a healthy latrine does not pollute the surrounding soil and water, is not accessible to insects, does not cause odor, is easy to care for, has a simple 
design, is cheap, and is accepted by the user [10]. Mubarak, Lilis, and Joko (2015) stated that there are diseases transmitted through feces, including Amoebiasis, Cholera, Shigellosis, Poliomyelitis, and Typhus [11].

In addition, the research echoes the work of Suriasumantri (2010) stating all that we know about something is obtained from scientific reasoning [12]. Rusman (2011) states that knowledge is a specific memory and general memory about various methods, processes, and structures [13]. Suriasumantri (2010) states that knowledge consists of three components: (1) cognitive components, (2) effective components, and (3) psychomotor components [12].

Adnil (2011) states that motivation is a force that exists in a person that can encourage, activate, move, and direct one's behavior [14]. Adnil (2011) further states that motivation consists of two parts, namely intrinsic and extrinsic motivation. Intrinsic motivation is the individual's encouragement to carry out activities that come from within the individual. Extrinsic motivation, namely individual encouragement that comes from outside himself [14].

Azwar (2012) states that attitude is a choice in terms of feelings, thoughts, and predisposes of action on environmental objects [15]. Ojedokun (2011) states that environmental attitudes are feelings to accept or reject issues related to the environment [16]. Azwar (2012) states that attitude consists of three components, namely: a cognitive part, namely what is believed, an affective part, namely what is felt emotionally, and a conative component, namely the tendency to act [15].

Hungerford, and Volk, (1990) stated that behavior is a series of human actions that are based on knowledge, motivation, attitudes, experiences, culture, economic conditions, and the environment [17]. Tukiyat (2009) states that behavior is the result of an act of someone who is carried out continuously [18]. Behavior should be directed towards positive things to the environment so that the environment can be sustainable.

The Law of the Republic of Indonesia Number 32 of 2009 and Ahmadi (2012) states that an environment is a spatial unit with all objects, forces and conditions, and living things, including humans and their behavior, which affect the continuity of life and welfare of humans and other living things [19]. Frytxell (2003) states that environmental knowledge can be defined as knowledge that has facts, concepts, and interactions with the natural environment and the entire ecosystem [20]. Adnani (2011) divides the environment into 3 parts, namely: Biological environment, physical environment, and social environment [14].

\section{Conclusion}

Knowledge, attitudes, motivation, and behavior of the low economic communities in the coastal areas of South Sulawesi tin making latrines that are safe for the environment before the experiment were at low levels and after experiments were in the high category The effect of the experiment is very significant in increasing the knowledge, attitudes, motivation, and behavior of the low economic community in the coastal areas of South Sulawesi in building latrines that are safe for the environment.

\section{Acknowledgements}

The acknowledgments are conveyed to:

1. Ministry of Research and Technology / National Agency for Research and Technology and the DirectorGeneral of Higher Education for funding this research as a form of coaching lecturers in Higher Education.

2. Rector of Makassar State University for his permission, guidance, and motivation so that this research is carried out well.

3. The head of the Institute for Research and Community Service (LP2M) Makassar State.

4. University for his support and direction in conducting this research well.

5. Soppeng and Sidrap District Governments for their support and granting of permits to conduct this research.

6. Farmers as research respondents for their participation and cooperation.

7. All members of the research team for their good cooperation.

8. All people who have participated in this research, were not mentioned one by one.

9. Hopefully what all the members and the team have done in completing this research can provide the greatest benefit for Makassar State University, Society, Nation, and State.

\section{References}

[1] Law of the Republic of Indonesia Number 32 of 2009 concerning Environmental Protection and Management.

[2] Singh, Y. K. (2006). Environmental Science. New Delhi: New Age International (P) Limited Publisher.

[3] Rauf, Bakhrani A, A. Muhammad Ardi, and Faizal Amir. (2018). Family latrine model for economically weak communities in lowland areas that are safe for the environment. Makassar: UNM Publishing Agency.

[4] Rauf., Bakhrani A. Muhammad Ardi, and Faizal Amir. (2017). The Family Latrine Model for the Weak Economic Community in an Environmentally Safe Coastal Area. Makassar: UNM Publishing Agency.

[5] Riski, Petrus (2015). Human Manure Is Turned Into Fertilizer and Energy. https:/www.mongabay.co.id/2015/04/20/manusia-diubah-jadi-pupuk-dan-energiditempat-ini/. Accessed 16 April 2018.

[6] Soemirat, J. (2014). Environmental Health. Yogyakarta: Gadjah Mada University Press.

[7] Borg \& Gall. (2007). Educational Research: An Introduction, 8th Edition. USA: Pearson.

[8] Fitriani, S. (2011). Health Promotion. Yogyakarta: Graha Science. 
[9] Firmansyah. (2009). Own and use a healthy latrine. http://www.wordPress.com. Retrieved May 25, 2015.

[10] Atika, A., (2012). Fecal Processing Methods. Surabaya: Buana Cipta Publisher.

[11] Mubarak W. I., Lilis I., Joko S. (2015). Textbook of Basic Nursing. Jakarta: Salemba Medika.

[12] Suriasumantri, J. S. (2010). Philosophy of Science A Popular Introduction. Jakarta: Pustaka Sinar Harapan

[13] Rusman. R (2011). Learning Models Developing Teacher Professionalism. Jakarta: PT. Rajagrafindo Persada.

[14] Adnani H. (2011). Public Health Sciences, Printing 1. Yoyakarta: Nuha Medika Publisher.

[15] Azwar, S. (2012). Human Attitudes, Theory and Measurement. Yogyakarta: Student Library Publisher.
[16] Ojedokun, O. (2011). "Attitude towards littering as a mediator of the relationship between personality attributes and responsible environmental behavior" Waste management journal 31 (12), 2601-2611.

[17] Hunggerfort, H. R, and Trudi L. Volk., (1990). Changing Learner Behavior Through Environmental Education. Unesco, UNDP, UNICEF, and World Bank. (www.elkhornsloughctp.org. Accessed March 20, 2014).

[18] Tukiyat., (2009). Behavior of Situ Rawa Besar Community in Managing the Environment. Synopsis of the Dissertation. Jakarta: Postgraduate Program, State University of Jakarta.

[19] Ahmadi. (2012). Social Psychology. Jakarta: Rineka Cipta.

[20] Frytxell, Gerald E. \& Lo, Carlos WH (2003). "The Influence of Environmental Knowledge and Values on Managerial Behaviors on Behalf of the Environment: An Empirical Examination of Managers in China." Journal of Business Ethics 46 (1): 45-69 (2003). 